\title{
QUALITY ASSESSMENT OF THE WOUND DRESSING PROCEDURE IN PATIENTS AT A UNIVERSITY HOSPITAL ${ }^{1}$
}

\author{
Eleine Aparecida Penha Martins Nonino² \\ Maria Luiza Anselmi ${ }^{3}$ \\ José Carlos Dalmas ${ }^{4}$
}

Nonino EAPM, Anselmi ML, Dalmas JC. Quality assessment of the wound dressing procedure in patients at a university hospital. Rev Latino-am Enfermagem 2008 janeiro-fevereiro; 16(1):57-63.

This observational and sectional study analyzed the quality of the wound dressing procedure performed on hospitalized patients at a medical surgical unit of a University Hospital, based on their classification according to the degree of care dependency and activity performance phases. Using a check list, 168 wound dressings were observed between October and December 2005. Procedure quality was analyzed based on the Positivity Index (IP) and values $\geq 70 \%$ were considered satisfactory.For the preparation, the IP was $68 \%, 63 \%, 73 \%$ and $75 \%$ for patients with degrees I, II, III and IV, respectively; for execution, 70\%, 69\%, 71\% and 75\% and, for unit organization, it was $\geq 70 \%$ for all degrees. However, the items: validity time frame checking, respect for aseptic principles and maintenance of logical sequence of procedures were compromised. Rigorous execution of procedures allows for risk decrease and assures benefic results for patients, conferring quality to nursing actions.

DESCRIPTORS: quality assurance, health care; nursing; bandages

\section{EVALUACIÓN DE LA CALIDAD DE LOS PROCEDIMIENTOS CURATIVOS EN PACIENTES INTERNADOS EN UN HOSPITAL UNIVERSITARIO}

Estudio observacional y seccional analizó la calidad del procedimiento curativo, realizado en pacientes internados en una unidad medico-quirúrgica de un Hospital Universitario, de acuerdo con el grado de dependencia asistencial y las fases de realización de la actividad. Con la utilización de un instrumento tipo check list fueran observados 168 curativos, entre octubre y diciembre 2005. La cualidad de los procedimientos fue analizada basada en el Índice de Positividad (IP) y fueron considerados satisfactorios aquellos que alcanzaron valores $\geq 70 \%$. En la preparación, el IP fue de $68 \%, 73 \%$ y 75\% para pacientes en grados I, II, III y IV, respectivamente; en la ejecución, fueran de $70 \%$, $69 \%, 71 \%$ y $75 \%$ y en la de organización de la unidad, en todos los grados fue $\geq 70 \%$. Entre tanto, los ítems: conferencia del plazo de validez de los materiales, respeto a los principios de asepsia y manutención de la secuencia lógica muestrearon se comprometidos. La ejecución rigorosa de un procedimiento posibilita reducción de riesgos, asegura resultados benéficos a los pacientes y confiere calidad a las acciones de enfermería.

DESCRIPTORES: garantía de la calidad de atención de salud; enfermería; vendajes

\section{AVALIAÇÃO DA QUALIDADE DO PROCEDIMENTO CURATIVO EM PACIENTES INTERNADOS EM UM HOSPITAL UNIVERSITÁRIO}

Estudo observacional e seccional analisou a qualidade do procedimento curativo desenvolvido em pacientes internados em unidade médico-cirúrgica de um Hospital Universitário, segundo grau de dependência assistencial e fases de realização da atividade. Entre outubro e dezembro de 2005, utilizando instrumento tipo check list, foram observados 168 curativos. A qualidade do processo desenvolvido foi analisada com base no Índice de Positividade (IP). Foram considerados satisfatórios os procedimentos que alcançaram valores $\geq 70 \%$. No preparo, o IP foi de $68 \%, 63 \%, 73 \%$ e $75 \%$ para pacientes em grau I, II, III e IV, respectivamente; na execução, de 70\%, 69\%, 71\% e $75 \%$ e na de organização da unidade, em todos os graus foi $\geq 70 \%$. Entretanto, os itens: conferência do prazo de validade dos materiais, respeito aos princípios de assepsia e manutenção da seqüência lógica mostraram-se comprometidos. A execução rigorosa de um procedimento reduz riscos e confere qualidade às ações de enfermagem.

DESCRITORES: garantia da qualidade dos cuidados de saúde; enfermagem; bandagens

${ }^{1}$ Paper extracted from Doctoral Dissertation; ${ }^{2}$ Ph.D., Faculty, Londrina State University, e-mail: eleinemartins@yahoo.com.br, ${ }^{3}$ Associate Professor, University of São Paulo at Ribeirão Preto College of Nursing, WHO Collaborating Centre for Nursing Research Development, Brazil, e-mail: anselmi@eerp.usp.br; ${ }^{4}$ Associate Professor, Londrina State University, Brazil. 


\section{INTRODUCTION}

Companies start to pay attention to quality as from the Industrial Revolution and the theme particularly occupies a central position as from the early $1930{ }^{\prime} \mathrm{s}^{(1)}$. Assuring competitiveness to the products available in the market, enlarging the profit margin and guaranteeing the economic-financial survival of the organization demands standardization and the use of evaluation instruments.

This way, the movement towards quality, primarily introduced into the industrial field and, soon after, into the field of services, expanded and gained ground in the daily life of health institutions ${ }^{(2)}$.

In the field of quality assessment in health,

Avedis Donabedian developed a conceptual theoretical framework that is used until today in the evaluation processes of health services and that involve the analysis of the following aspects: structure, process and result ${ }^{(3)}$.

The structural assessment comprises: physical, human, material and financial resources necessary for health care; the process corresponds to the set of activities developed in the relation between professionals and users; the result refers to the changes verified in the health condition of patients which can be attributed to previous care and, also, changes related to knowledge and behavior and the user's satisfaction with the delivered care $^{(3-4)}$.

Recently, as from the 1990's, the Hospital Accreditation program has been implemented in Brazil. It constitutes a method of external evaluation performed by peers in the health field. It is developed based on previously established well-known standards, which contemplate structure, process and result elements ${ }^{(5)}$ and aims to stimulate the development of "a continuing quality culture of medical-hospital care and health protection to the population"(1).

The evaluation for Hospital Accreditation is carried out based on the Brazilian Manual of Hospital Accreditation. The nursing service is contemplated in this manual, and the standards established for evaluation allow for the quality verification of the nursing care delivered to clients.

The nursing field is responsible for integral direct care delivery to the patient as a biological and social being, differing two specific fields of activities: the care, comprehending the procedures, and nursing care administration ${ }^{(6)}$.

In Brazil, nursing work is historically configured by its division in different categories of agents. On the one hand, the nurses are a minority category and are attributed with the actions of teaching and management; and, on the other side, nursing auxiliaries and technicians, whose work focuses on nursing care and particularly technical procedures ${ }^{(7)}$.

Among the actions developed by the nursing team, the technical procedures hold risks and, in this case, require continuous evaluations by the nursing service, in order to assure the quality of the care process $^{(7)}$.

In the literature review about the evaluation of nursing techniques in the databases LILACS and Medline, in the period from 1996 to 2005, with descriptors extracted from Descriptors in Health Sciences: evaluation, (followed by: bandages, nursing), process evaluation (health care) (followed by: bandages, nursing) and results evaluation (health care) (followed by: bandages, nursing), few studies were found which evaluate the quality standard of nursing procedures' execution through direct observation.

Among these, the assessment of nurses', nursing auxiliaries' and technicians' performance through direct observation in the execution of peripheral venous puncture should be mentioned. The results indicate inadequacies in the performance among the three categories of professionals ${ }^{(8)}$. Another investigation, supported by the Ministry of Health, evaluated the performance of nursing auxiliaries, technicians and attendants for inhalation, venous puncture for medication and intramuscular medication, at three hospital services in Bahia. The same study found unsatisfactory performance for all techniques in the three professional categories ${ }^{(9)}$.

A study on the execution of aseptic and septic dressings in a district health center found out that $57.4 \%$ of the 101 aseptic dressings made presented an unsatisfactory performance standard; and that $20.8 \%$ of the 206 septic dressings were executed unsatisfactorily ${ }^{(10)}$.

The quality of the services delivered by a health institution greatly depends on the technical competence and interaction and communication ability of its employees towards the user, but also on other aspects, such as current working conditions, material resources and support services available.

Among the technical procedures frequently performed by nursing professionals, dressings stand out, which consist in cleaning and covering the wound with the purpose of supporting the wound treatment or preventing colonization in the insertion locations of diagnostic and therapeutic invasive devices ${ }^{(11)}$ and 
promoting wound healing, avoiding infection and decreasing costs and damages for the patient.

In practice, dressing is a procedure predominantly performed by nursing auxiliaries and technicians, while the nurse is responsible for supervising, providing products according to the availability at the institution, guide, follow up, develop educative processes and evaluate the employees.

Considering that, in the nursing care process, the technical dressing procedure involves risks that can compromise nursing care quality, this study was developed to evaluate the quality of this procedure according to the patient's dependence level at a medical surgery ward of a teaching hospital in Paraná. Expectations include the identification of satisfactory and / or unsatisfactory aspects, the proposal of steps that contribute to the improvement of professional practice and evaluation processes of health care quality at the study institution.

\section{METHOD}

This is an observational and sectional study developed at a teaching hospital in the North of Paraná, which in 2005 offered 333 active beds and 816 employees.

The hospital ward studied was the male medical surgery ward, which in 2005 had a total of 73 active beds (about $22 \%$ of the total number of beds at the hospital), nine nurses, ten nursing technicians and 42 nursing auxiliaries.

The hospital has a Department of Quality Control in Nursing Care, which every three months monitors the working processes and nursing care quality and, when necessary, offers training for the improvement of the nursing team.

The Systemization of the Nursing Care has been implanted 24 years ago and, today, the stages of history, nursing prescription and annotations are developed.

The study population consisted of dressings performed by the nursing team in hospitalized patients, classified by their dependence level (I, II, III and IV), according to a readapted instrument ${ }^{(12)}$ and who presented one single wound. These levels represent, in an ascending way, the patient's dependence on nursing care for: walking, bathing, eating, behavior, self-care, medication, pre and post-operative care and life maintenance. This classification supports the development of the nursing process, organizing and guiding nursing work and permitting an evaluation of the procedures performed by the professionals ${ }^{(12)}$.
The data collection technique was direct observation and the instrument used was a checklist, elaborated based on observations of literature on the subject ${ }^{(11,13-16)}$, considering the working process of the nursing team, the patients' basic human needs and the peculiar characteristics of the technique in the phases of preparation, execution and unit organization. For the latter, it is important to make clear that, according to the established routine, the employees register all dressings in patients' files only at the end of their shift, which complicated the presence of the researchers in the field until the moment the dressing was registered and, consequently, the observation of this action, which was excluded from the instrument.

Also, a manual was developed which follows the instrument, including the descriptors of each item to be observed. Both (instrument and manual) were validated regarding the content by nine judges considered experts in the subject; four of them were nursing faculty and the other five clinical nurses. After incorporating the suggestions, the instruments were tested at a medical surgical unit, with the observation of 28 dressings.

The presentation of each item is followed by three answer options: "yes" (when the item is performed correctly), "no" (when the item is not performed), "not applicable" (when the item is not applicable to the situation observed) and also a space for comments. The direct observations were made by a nurse and 11 nursing students, who were called field researchers and had been selected and trained for this study.

Data were collected in the period from October to December, 2005, at mornings, in a total period of 45 days. The researchers were available at the unit and, as they identified an employee who was going to perform a dressing, they made their observation and at the same time classified the patients at their corresponding dependence level.

The study was approved by the Research Ethics Committee at the Federal University of Londrina and 20 employees from the unit signed the Free and Informed Consent Term.

The collected data were typed and stored in an Excel database. For analysis, the Positivity Index (PI) was used, which consists in identifying, for each item of the instrument, the kind of answer observed (affirmative, negative or not applicable). When a situation in which the patient was not exposed to the observed condition was verified, the item was disregarded in the analysis, as its inclusion in the equation would underestimate the data obtained for the index. After applying the equation 
below, the percentage of positivity for each instrument item was obtained and, next, for the set of items according to the dependence level of the patient in every phase of the procedure.

$$
\text { Positivity Index }(\mathrm{PI})=\left(\frac{r a}{r a+r n}\right) \bullet 100
$$

In which: $r a=$ affirmative answers and $r n=$ negative answers

Based on the consulted literature ${ }^{(8-9)}$, the Positivity Index (PI) equal to or higher than $70 \%$ was used as the parameter for dressing quality assessment.

\section{RESULTS}

The study observed 168 dressings, performed by 20 employees: 55\% nursing technicians and $45 \%$ nursing auxiliaries, with a predominance of female professionals (70\%), an average of 40 years old and an average period of eight years working in the nursing area.

From the 168 dressings, 57 (33.9\%) were performed in patients classified at dependence level I, $65(38.7 \%)$ at level II, $33(19.6 \%)$ at level III and $13(7.8 \%)$ at level IV. Thus, the dressings were predominantly observed in patients classified at levels I and II.

It was decided to present the data with full values, according to the tables below. Table 1 shows the PI found in the dressing preparation phase.

Table 1 - Positivity Index (\%) in the "Dressing Preparation" phase, according to the dependence level of the patients at the medical surgery ward of the hospital. HU/UEL. Londrina, 2005

\begin{tabular}{|c|c|c|c|c|}
\hline \multirow[b]{2}{*}{ Dressing Preparation } & \multicolumn{4}{|c|}{$\mathbf{P I}$} \\
\hline & $\begin{array}{l}\text { Level I } \\
(\mathrm{n}=57)\end{array}$ & $\begin{array}{l}\text { Level II } \\
(n=65)\end{array}$ & $\begin{array}{l}\text { Level III } \\
(n=33)\end{array}$ & $\begin{array}{l}\text { Level IV } \\
(n=13)\end{array}$ \\
\hline $\begin{array}{l}\text { Does he/she introduce himself/herself } \\
\text { to the patient? }\end{array}$ & 29 & 29 & 50 & - \\
\hline $\begin{array}{l}\text { Does he/she explain the proposed } \\
\text { procedure? }\end{array}$ & 79 & 74 & 92 & 67 \\
\hline $\begin{array}{l}\text { Does he/she prepare the material for } \\
\text { the dressing individually? }\end{array}$ & 100 & 100 & 100 & 100 \\
\hline $\begin{array}{l}\text { Does he/she prepare material for } \\
\text { more than one dressing? }\end{array}$ & 100 & 100 & 100 & 100 \\
\hline $\begin{array}{l}\text { Does he/she heat the physiological } \\
\text { serum? }\end{array}$ & 03 & 02 & 07 & 0 \\
\hline $\begin{array}{l}\text { Does he/she wash hands before } \\
\text { starting a dressing? }\end{array}$ & 47 & 33 & 38 & 45 \\
\hline $\begin{array}{l}\text { Is there any need to position the } \\
\text { patient for the dressing? }\end{array}$ & 100 & 96 & 95 & 100 \\
\hline $\begin{array}{l}\text { Does he/she maintain the privacy } \\
\text { and integrity of the patient during the } \\
\text { procedure? }\end{array}$ & 100 & 90 & 100 & 100 \\
\hline Total & 68 & 63 & 73 & 75 \\
\hline
\end{tabular}

It is observed that the dressings made in patients classified at levels III and IV obtained satisfactory total positivity rates of more than $70 \%$, while those made in patients at levels I and II presented rates below expected levels.

Analyzing the different items that compose the preparation phase, there is evidence of commitment in the "introduction to the patient", "heating the physiologic serum" and "washing hands before starting the dressing", in which the PI was $\leq 50 \%$. At level IV, the explanation of the procedure to the patient was carried out in $67 \%$ of the observations, perhaps because, at this level, the patient may present a decreased level of conscience, impairing communication, although there was no record of any kind of interaction between nursing professionals and patient.

Table 2 presents Positivity Index data in the execution stage of the dressing procedure.

Table 2 - Positivity Index (\%) in the "Dressing Execution" phase, according to the dependence level of the patients at the medical surgery ward of the hospital. HU/UEL. Londrina, 2005

\begin{tabular}{|c|c|c|c|c|}
\hline Dressing Execution & $\begin{array}{l}\text { Level I } \\
(n=57)\end{array}$ & $\begin{array}{c}\text { Level II } \\
(n=65)\end{array}$ & $\begin{array}{l}\text { PI } \\
\text { Level III } \\
(n=33)\end{array}$ & $\begin{array}{l}\text { Level IV } \\
(n=13) \\
\end{array}$ \\
\hline $\begin{array}{l}\text { Did he/she prepare the environment } \\
\text { properly? }\end{array}$ & 34 & 31 & 29 & 63 \\
\hline $\begin{array}{l}\text { Did he/she open the dressing package } \\
\text { properly? }\end{array}$ & 93 & 70 & 82 & 85 \\
\hline $\begin{array}{l}\text { Did he/she check the expiry date of the } \\
\text { material? }\end{array}$ & 0 & 17 & 6 & 0 \\
\hline $\begin{array}{l}\text { Did he/she keep the position / } \\
\text { disposition of the material properly? }\end{array}$ & 72 & 77 & 85 & 77 \\
\hline $\begin{array}{l}\text { Did he/she keep the garbage distant } \\
\text { from the wound or next to the nippers of } \\
\text { the first time? }\end{array}$ & 77 & 80 & 82 & 83 \\
\hline $\begin{array}{l}\text { Did he/she use the solution prescribed to } \\
\text { clean the wound? }\end{array}$ & 98 & 97 & 100 & 100 \\
\hline Did he/she keep a logical sequence? & 27 & 17 & 67 & 91 \\
\hline $\begin{array}{l}\text { Was the first portion of PVPI, safgel or } \\
\text { papaina tube thrown away? }\end{array}$ & 84 & 69 & 85 & - \\
\hline $\begin{array}{l}\text { Did he/she keep the asepsis principle } \\
\text { during the dressing? }\end{array}$ & 61 & 71 & 52 & 85 \\
\hline $\begin{array}{l}\text { Did he/she choose the cover } \\
\text { recommended by the nurse or did } \\
\text { he/she follow the nursing prescription? }\end{array}$ & 100 & 94 & 100 & 92 \\
\hline $\begin{array}{l}\text { Does he/she consider the pain } \\
\text { complaints of the patient taking conduct? }\end{array}$ & 91 & 87 & 80 & 100 \\
\hline Total & 70 & 69 & 71 & 75 \\
\hline
\end{tabular}

Except for level II (69\%), at the other levels, the total PI reached the recommended level of $\geq 70 \%$. This level was reached at least seven items at the four dependence levels.

In some items however, the PI is below $70 \%$, namely: "the environment was properly prepared" ( $\leq$ $63 \%)$; "the expiry date of the material was checked" $(\leq 17 \%)$; and professionals never complied with this item at levels I and IV. 
Another item compromised in the positivity was "a logical sequence was kept", because the verified $\mathrm{PI}$ is below $70 \%$ in the dressings of patients at levels I (27\%), II (17\%) and III (67\%). Levels were satisfactory at level IV only. The descriptor of this item demands the use of nippers according to the four periods of the procedure execution ${ }^{(13,16)}$. When the nippers are substituted by gloves, the logical sequence and the asepsis principle need to be maintained, which are elements that contribute to decreased infection rates in the surgical area(16-17).

For the item "the asepsis principle was kept during the dressing", in patients at levels I and III, the PI was below recommended levels, in other words, $61 \%$ and $52 \%$, respectively.

Table 3 exposes Positivity Index data in the unit organization phase after the end of the dressing.

Table 3 - Positivity Index (\%) in the "Unit Organization" phase, according to the dependence level of patients at the medical surgery ward of the hospital. HU/UEL. Londrina, 2005

\begin{tabular}{|c|c|c|c|c|}
\hline \multirow[b]{2}{*}{ Unit Organization } & \multicolumn{4}{|c|}{ PI } \\
\hline & $\begin{array}{l}\text { Level I } \\
(n=57)\end{array}$ & $\begin{array}{l}\text { Level II } \\
(n=65)\end{array}$ & $\begin{array}{l}\text { Level III } \\
(n=33)\end{array}$ & $\begin{array}{l}\text { Level IV } \\
\qquad(n=13)\end{array}$ \\
\hline $\begin{array}{l}\text { Did he/she throw the used materials } \\
\text { away right after the end of the } \\
\text { dressing and into the right places? }\end{array}$ & 100 & 100 & 100 & 100 \\
\hline $\begin{array}{l}\text { Did he/she throw the used materials } \\
\text { away after the end of several } \\
\text { dressings? }\end{array}$ & 94 & 100 & 100 & 100 \\
\hline $\begin{array}{l}\text { Did he/she wash hands or use alcohol } \\
\text { gel after the end of each dressing? }\end{array}$ & 49 & 39 & 48 & 58 \\
\hline Total & 73 & 70 & 75 & 80 \\
\hline
\end{tabular}

The obtained total positivity rates were $\geq 70 \%$. Even reaching satisfactory total positivity rates in all levels, hand asepsis at the end of the dressing execution is compromised at the four levels of dependence, with PI rates varying from 39\% at level II to $58 \%$ at level IV, a fact that can favor cross infection.

\section{DISCUSSION}

The results obtained indicate that communication was deficient, although we consider that, in integral nursing care, technical and communication dimensions are indissoluble ${ }^{(9)}$. Research on the execution of nursing techniques in hospitals in the state of Bahia also found an unsatisfactory performance of nursing professionals in the communication/interaction items with the patient ${ }^{(9)}$.
Regarding the item "heating of the physiologic serum", this stage is considered essential in the execution of a dressing, because it is associated to improved healing, preservation of biochemical and enzymatic cell reactions, increased circulation and oxygen tension in the wound and increased cellular immunity with the decrease of bacterial contamination $^{(14,16-18)}$.

A stove is available at the unit, but it is generally turned off. It is up to the nurses, through managerial actions, to assure the provision and availability of equipment, appropriate material existing in the institution, as well as supervision and follow-up of team work in order to permit the satisfactory execution of the nursing procedures.

Another fact that stands out was the lack of hand washing before and after the procedure. Although the department relies on an expressive quantity of active beds (73) distributed in 11 wards, and few washbasins available in the corridors, there are containers with alcohol gel in each infirmary, not justifying the results obtained. It is evident that the habit of hand washing or using alcohol gel is not incorporated as an important nursing action in the prevention of risks for patients and employees.

International studies indicate health professionals' low adherence to this procedure in different departments. The reasons that contribute to the latter are: disbelief in the risk of pathogen transmission, negligence, lack of material and difficult access to alcohol or alcohol gel dispensers ${ }^{(19-20)}$. In Brazilian literature, studies also identify that hand washing before and after the execution of nursing procedures is deficient, exposing the patient to hospital infection risks. However, the causes of this behavior are not pointed out ${ }^{(8-9)}$

This procedure item involves other behavioral aspects besides the technical dimension, such as changes in attitudes, beliefs and employee motivation $^{(20)}$. In this matter, hand hygiene demands a more direct supervision of the nurse during the procedure execution. Educational processes are needed that favor the modification of already consolidated habits.

Another aspect that was compromised was the verification of the material expiry date. In the study hospital, the center of material distribution makes kits that contain a package of dressings, tissue and gloves. As the employee does not check the material expiry date, it is possible that (s)he ends up making the dressing with a clean but not sterile 
technique according to recommendations for a hospital environment ${ }^{(11,16)}$, endangering the patient.

Concerning the logical sequence of the procedure, which showed implications, there is the fact that, in clean wounds, it is recommended to start cleaning from the less contaminated to the more contaminated areas, in other words, from the center to the adjacent areas of the wound; and, in the contaminated wounds, following the same principle, the dressing should start in the adjacent areas and borders and finish at the center or inside the wound. This principle helps to decrease the occurrence of synergisms in bacteria action, which cause larger wounds in the adjacent areas, avoid the dissemination of microorganisms in ulcerated wounds, abscess and surgical dehiscence and clean areas ${ }^{(11,13,16)}$.

In some situations, for different reasons, contradicting what it is advised in literature ${ }^{(11,13)}$ there was contamination of the nippers: due to inadequate handling, leading to crossing among them; by the hands touching the sterile field; by lifting the nippers improperly at the center of the sterile field or by disrespecting the field limit that was divided into sterile and not sterile (where the part of the nippers that we touch is placed). It was also verified that the gloves were not changed from the first to the second time, when the dressing execution with gloves was the chosen option.

Regarding the environment organization, the employees' concern with this aspect is evidenced when they discard the materials properly, not allowing them to be dispersed in the infirmaries. This behavior can be due to the nursing supervision process, in which the nurse detects problems related to the infirmary organization more easily, like dressing leftovers, dispersed nippers and misplaced garbage. Thus, the employee is determined to perform the activities satisfactorily.

According to the Brazilian Manual of Accreditation, for nursing, it is necessary among other aspects to: identify, define, standardize and document its processes; establish procedures; measure and evaluate the process results ${ }^{(5)}$. In other words, improperly developed dressings that do not attend to the basic principles of asepsis and to the recommended logical sequence compromise care quality, as they imply infection risks both to the patient and the employee and can delay the healing process and, thus, extend hospital stay, increasing costs.

In this matter, the execution of dressings by nursing represents an important activity in the care process and, in other words, a standardized execution that rigorously obeys the technical-scientific principles and professional-user interaction, will contribute to the quality of the care offered by the institution.

The use of protocols and the development / implementation of training processes that enable both nurses and the other team members to execute this procedure permit the improvement of professional performance and, eventually, assure certain quantitative and qualitative standards of health care $^{(9)}$.

\section{CONCLUSIONS}

The procedure execution was satisfactory in the dressing preparation phase for patients at levels III and IV, 73\% and 75\% respectively; in the execution phase, for patients at levels I, III and IV (70\%, 71\% and $75 \%$ ). For those at level II the Positivity rate was $69 \%$, which is very close to the established parameter; in the unit organization phase, the PI obtained at all levels was $\geq 70 \%$.

However, in some items, the positivity was below the expected, including: communication with the patient; verification of the material expiry date; respect for the logical sequence of procedure development and asepsis principles. These results indicate that the dressing execution, at the selected unit, can raise the risks of infection, compromising the healing and recovery process of the patient's skin integrity, thus demanding a longer hospital stay. Such aspects address the need for better work supervision by the unit nurses which, when developed together with other team members, will contribute to improve the performance of the employees and to assure the quality in care processes.

The study limitations include the absence, in the data collection instrument, of the item about the wound cleaning method, which was not identified by the judges; as well as the procedure execution record in the patient's file, elements that can also interfere in the quality. It is also important to mention the lack of studies to evaluate procedures through direct observation, using indices for measuring the quality, which complicated the comparison of the results with literature.

Also, the observation technique based on a checklist corresponds to a quality standard in the execution of the procedure under study, and it will be able to constitute a valuable instrument for education, health service management and other studies on nursing practice. 


\section{REFERENCES}

1. Malik AM, Schiesari LM. Qualidade na gestão local de serviços e ações de saúde. São Paulo (SP): Faculdade de Saúde Pública da Universidade de São Paulo; 2002 (Série Saúde \& Cidadania).

2. Braz MG. Indicadores de qualidade na assistência domiciliar: Uma proposta de indicadores de qualidade e desempenho. PRONEP 2002; 1-14.

3. Donabedian A. The definition of quality and approaches to its assessment: explorations in quality: explorations in quality assessment and monitoring. Chicago: Health Administration Press; 1980.

4. Silva LM, Formigli LA. Avaliação em saúde: Limites e perspectivas. Cad Saúde Pública 1994 janeiro-março; 1(10): 80-91.

5. Organização Nacional de Acreditação. [Homepage na internet]. Brasilia: Anvisa; Manual de acreditação das organizações prestadoras de serviços hospitalares. [acesso 31 julho 2006]. Disponível em: http:www.anvisa.gov.br/ servicosaude/acreditacao/manual/glossario.pdf

6. Lunardi VL, Malheiro AD, Caurio DP, Lunardi WD, Chaplin MJ. Problemas no cotidiano do trabalho e sua relação com o cuidado de si e o cuidado do outro. Rev Gaucha Enfermagem 2000 julho; 21(2):125-40.

7. Peduzzi M, Anselmi ML. Os pressupostos, o desenho e os resultados da pesquisa de avaliação do impacto do PROFAE na qualidade dos serviços de saúde. In: Castro JL, organizadora. Profae: Educação profissional em saúde e cidadania. Brasília (DF): Ministério da Saúde (BR); 2002. p.151-64.

8. Torres MM, Andrade D, Santos CB. Punção venosa periférica: Avaliação de desempenho dos profissionais de enfermagem. Rev Latino-am Enfermagem 2005; 13(3):299304.

9. Peduzzi M, Anselmi ML, França I Junior, Santos CB. Qualidade no desempenho de técnicas dos trabalhadores de enfermagem de nível médio. Rev Saúde Pública 2006; $40(5): 843-50$.

10. Ribeiro CMM. Dimensionamento de recursos humanos em enfermagem, nas salas de curativo de uma unidade de saúde de Ribeirão Preto-SP. [dissertação]. Ribeirão Preto (SP): Escola de Enfermagem de Ribeirão Preto/USP; 2001. 11. Jorge AS, Dantas SRPE. Abordagem multiprofissional do tratamento de feridas. São Paulo (SP): Atheneu; 2003.

12. Martins EAP, Haddad MCL. Validação de um instrumento que classifica os pacientes em quatro graus de dependência da assistência de enfermagem. Rev Latino-am Enfermagem 2000 abril; 8(2):74-82.

13. Mussi NM, Ohnishi M, Utyama IKA, Oliveira MMB. Técnicas fundamentais de enfermagem. São Paulo: Atheneu; 1996.

14. Dealey C. Cuidando de feridas: um guia para enfermeiros. $2^{a}$ ed. São Paulo (SP): Atheneu; 2001.

15. Bryant AR. Acute and Chronic wounds nursing management international association for enterostomal therapy. St. Louis: Mosby Year Book; 1992.
16. Borges EL, Saár SRC, Lima VLAN, Gomes FSL, Magalhães MBB. Feridas: como tratar. Belo Horizonte (MG): Coopemed Editora Médica; 2001.

17. Universidade Estadual de Campinas (SP). Grupo de Estudos de feridas: tratamento de feridas. Campinas (SP): UNICAMP; 1999.

18. Withney JD, Wickline MM. Treating chronic and acute wounds with warming: Review of the Science and Practice Implications. JWOCN 2003 July; 30(4):199-209.

19. Rosenthal VD, McCormick RD, Guzman S, Villamayor C, Orellano PW. Effect of education and performance feedback on handwashing: the benefit of administrative support in Argentinean hospitals. AJIC 2003; 31(2):85-92.

20. Pittet D. Hand hygiene: improved standards and practice for hospital care. Current Opinion Infect Dis 2003; 16(4):327-35. 